\title{
Wyrok Sądu Metropolitalnego w Katowicach (c. Sobański) z 27.12.2000 r. z tytułu symulacji (absentia consensus)
}

Ius Matrimoniale 7 (13), 207-212

2002

Artykuł został zdigitalizowany i opracowany do udostępnienia w internecie przez Muzeum Historii Polski w ramach prac podejmowanych na rzecz zapewnienia otwartego, powszechnego i trwałego dostępu do polskiego dorobku naukowego i kulturalnego. Artykuł jest umieszczony w kolekcji cyfrowej bazhum.muzhp.pl, gromadzącej zawartość polskich czasopism humanistycznych i społecznych.

Tekst jest udostępniony do wykorzystania w ramach dozwolonego użytku. 


\section{Wyrok Sądu Metropolitalnego w Katowicach (c. Sobański) z 27.12.2000 r. z tytułu symulacji (,absentia consensus”)}

\section{Przebieg sprawy:}

AS oraz GB zawarli małżeństwo 23.7.1994 w kościele Matki Bożej Częstochowskiej w K. Ważność tego małżeństwa zaskarżyła GB skargą, jaka wplynęła do Sądu Metropolitalnego 3.12.1998. Powódka wniosła o orzeczenie nieważności małżeństwa „z tytułu fałszywego ślubowania i niezdolności do zawarcia małzeństwa wobec niedojrzałości psychicznej powodującej brak rozeznania co do istotnych praw i obowiązków małżeńskich po stronie pozwanego". Skargę przyjęto do procesu 4.2.1999, a jego przedmiot ustalono $18.3 .1999 \mathrm{w}$ formie pytania: czy zachodzi nieważność małżeństwa stron z tytułu symulacji małżeńskiej lub niezdolności do podjęcia istotnych obowiązków małżeńskich po stronie pozwanego?" Instrukcja sprawy przedłużała się $\mathrm{z}$ wielu przyczyn, wśród nich obstrukcji procesowej pozwanego, oczekiwania na dowody zapowiedziane przez pełnomocnika powódki, wniosku o przedlużenie terminu przedłożenia głosu obrończego.

\section{Motywy prawne:}

Wchodzące $\mathrm{w}$ grę przepisy prawa materialnego to kan. $1055 \S 1$, $1057,1095 \S 3,1101$.

\section{Stan faktyczny:}

1. Powódka zeznaje, że propozycja matrymonialna „wyszła raczej z jego strony", powódka się zgodziła, bo kochała pozwanego. Ustalono, że powódka wyjedzie do pozwanego do Niemiec, pozwany przedstawial przyszlość „w różowych kolorach”. Nikt jej nie odradzal tego małżeństwa, nie dostrzegła żadnych dziwnych zachowań pozwanego, 
mimo że jej rodzina zwracała jej na takie uwagę. Po ślubie pozwany „już wprost mówil, że dzieci nie chce" - i dlatego powódka wnosząc symulacje jako tytuł nieważności uważa, „że pozwany wykluczył z małżeństwa potomstwo". Zaczął powódkę źle traktować, przedmiotowo, czula się „zupelnie nieważna w życiu pozwanego”, jej rola „praktycznie sprowadzała się do lóżka”, musiała „prosić się o każdy grosz”, zupełnie nie liczył się z jej zdaniem, znikał $z$ domu na całe wieczory a jego matka wyrzucala powódce, że powinna umieć zatrzymać go bardziej w domu, więcej mu nadskakiwać. Pozwany coraz bardziej dokuczal jej psychicznie i fizycznie, a gdy przyjechali na Wielkanoc do Polski, to ją po prostu odstawil, nie przyjął jej już do swego mieszkania.

2. Pozwany odmówił udziału w sprawie. Jego zachowania trudno uznać za poważne. W komunikacie elektronicznym podaje, że ma „kłopoty z pisaniem po polsku” i prosi o korespondencję w języku niemieckim. Pismo skierowane do audytora Sądu Arcybiskupiego w Kolonii świadczy, że z ,pisaniem po niemiecku” ma nie mniejsze klopoty. Swój profil kulturowy i poziom intelektualny zademonstrowal w piśmie z 14.12.1998: „pragnę zapytać Wysoki Sąd, czy Kościól Polski wraca do czasów Św. Inkwizycji”. W telefonicznej rozmowie $z$ audytorem oświadczył, że sprawa jest mu obojętna.

3. W sprawie zeznawało czworo świadków.

Dla IB, matki powódki, jest niezrozumiale, że pozwany tak bardzo dążył do małżeństwa, nie słuchając rad, by jeszcze odczekać, a potem „tak szybko niszczył to małżeństwo". Świadek uważa, że pozwany „nie ślubował szczerze”, bo gdyby był szczery, to przeciez „ratowałby ten ich związek, a on robil coś przeciwnego". Swiadek nie potrafi jednak wyjaśnić, co nim kierowało i co wykluczał $z$ tego swojego małżeństwa, bo generalnie wydawało się, że chce tego małżeństwa". Świadek ostrzegala powódkę, ale ta nie dała sobie nic powiedzieć, „była całkiem zaślepiona”. W kilka miesięcy po ślubie świadek zaobserwowała „dziwne zachowania pozwanego - on o byle co wpadał w złość i wybuchał strasznym gniewem. Gdzieś w lutym powódka „strasznie płakała i mówiła, że takiego życia już dłużej nie wytrzyma, że pozwany ją dręczy, straszy, robi awantury", a na Wielkanoc przywiózl powódkę ,jak paczkę".

AM wie $z$ pojedynczych kontaktów, że pozwany będąc jedynakiem dobrze rozumial się ze swym ojcem, matka nie miała w tym domu wiele do powiedzenia. Byl typem cholerycznym, latwo wybuchowym, trudnym w kontakcie. Swiadek nie zna poglądów pozwanego na małżeństwo, nie wie, czy ślubował szczerze - wrażenie świadka było takie, że 
pozwany nie był zachwycony ślubem kościelnym, wyraził się, że za wydane w związku z tym pieniądze można było kupić sobie coś lepszego. Po ślubie pozwany wciąż miał powódce coś do zarzucenia, małżeństwo stało się dla niej męczarnią - pozwany odgrywał rolę bossa, tak jak był do tego $z$ domu przyzwyczajony. Pozwany wedle świadka wcale nie jest typem silnego człowieka, za jakiego pragnie uchodzić. Świadek potwierdza relację powódki o rozpadzie małżeństwa, zachowanie pozwanego było szokujące.

Wedle babci powódki, AP, której pozwany przed ślubem podpadł jedynie swą nerwowością, on po ślubie „bardzo się zmienil”. Swiadek nie wie, czy pozwany ślubował szczerze, na podstawie zachowań poślubnych „można mieć wątpliwości”. W dniu ślubu zażył trzy tabletki relanium, ale „ślub i wesele minęły normalnie”. Świadek odwiedziła strony na święta Bożego Narodzenia i stwierdzila wtedy, że powódka bardzo źle wygląda, pozwany traktował ją i gości bardzo źle, a w pierwsze święto Bożego Narodzenia zamiast do kościoła poszedl do solarium.

Przesłuchano też proboszcza, który spisywał protokół przedślubny i dobrze pamięta to wydarzenie. Zeznaje: „Powódkę znałem z parafii, także ze spotkań młodzieżowych, jako spokojną i dobrą dziewczynę. I ta dziewczyna przyszla kiedyś do mnie na probostwo do spisania protokołu, przyprowadzając chłopaka, który zaczął się do mnie zwracać bardzo łamaną polszczyzną - zapytałem go, dlaczego tak źle mówi po polsku, i on mi wyjaśnil, że od kilku lat mieszka w Niemczech. Jestem na te sprawy bardzo wyczulony i zrobilem mu taką małą awanturę powiedziałem mu, że będę mu w takim razie zadawał pytania $z$ protokołu po niemiecku, niech on odpowiada też po niemiecku, a ja to sobie wpiszę po polsku. Wtedy tego chłopaka zatkało - nagle odzyskal bardzo poprawną mowę w języku polskim. Powiedziałem mu, co o tym myślę, a powódce zwróciłem uwagę, że ten jej chłopak jest nieodpowiedzialny i głupkowaty. Radziłem jej nawet, aby się zastanowiła, czy za niego wychodzić za mąż. Powódka była jednak chyba zakochana, może też wizja wyjazdu na stałe do Niemiec odgrywała tu jaką́s rolę, w każdym razie nie rozmyśliła się co do tego ślubu. W trakcie spisywania protokolu pozwany próbował jeszcze mądrować i zgrywać ważnia$\mathrm{ka}$, ale ucinałem te jego wywody i chciałem od niego tylko odpowiedzi „tak” lub „nie”. Więcej się z tym czlowiekiem już nie spotkałem”.

Pozwany wedle proboszcza „zgrywal nie wiadomo kogo”. Tenże proboszcz podal w świadectwie z 26.3.1999, że sugerowal powódce 
wówczas, ,aby dobrze przemyślala sprawę, ponieważ narzeczony wydawał mu się nieodpowiedzialny i niepoważny".

4. Material przedłożono biegłej-psycholog, która wobec braku szans na badanie pozwanego zinterpretowała material zawarty $w$ aktach sprawy. Biegła stwierdza, że nagromadzony materiał nie pozwala wydać jednoznacznej opinii o braku zdolności pozwanego do podjęcia istotnych obowiązków małżeńskich. Wedle biegłej „zachowanie pozwanego wskazuje bardziej na wyrachowanie z jego strony niz na brak zdolności natury psychicznej”. Biegła uważa, że pozwany „działał w sposób świadomy i kontrolowany". Jego zachowania zostały przez świadków odebrane jako gra, trudno jednak określić, co „naprawdę chciał odegrać".

5. Oceniając materiał dowodowy Sąd stwierdza, że brak wystarczających dowodów na powodowaną czynnikami natury psychicznej niezdolność pozwanego do podjęcia istotnych obowiązków małżeńskich. Zachowania pozwanego mogą nastręczać wątpliwości co do jego zdolności do nawiązania wspólnoty małżeńskiej, polegającej przecież na wzajemnym przyjęciu i oddaniu się dwojga osób. Zachowania pozwanego niewątpliwie wykazują cechy patologiczne, są to zachowania osobnika niedojrzałego, nie adekwatne do sytuacji.

Brak jednak dowodów na to, że patologia jest tak głęboka, że pozwany nie jest $w$ stanie zapanować nad swym zachowaniem $i$ - tym samym - niezdolny do zachowania odmiennego. Pozwany - wydaje się potrafi się dostosować, dopasowuje swe zachowanie do sytuacji - zachowania przedślubne, zmiana stylu przy protokole przedślubnym. O ile nie można mówić z pewnością o defekcie psychicznym, o tyle wyraziście rysują się defekty charakterologiczne. Zostały one zauważone i odnotowane w związku z zawieraniem malżeństwa. Pozwany zgrywał i wymądrzał się, usiłowal wyrazić swe opinie także przy spisywaniu protokołu przedślubnego, wygadywal tak, że proboszczowi trudno byto zachować równowagę Skoro to wymądrzanie się miało miejsce przy protokole przedślubnym, to trzeba przyjąć, że dotyczyło malżeństwa. Zachowanie przy spisywaniu protokolu przedślubnego, określone przez proboszcza jako ,nieodpowiedzialne i niepoważne”, trudno pogodzić z wolą zawarcia prawdziwego małżeństwa. Skłonność do popisywania się swą „mądrością" pozwany wykazuje do dziś, o czym świadczą jego pisma do Sądu. Odpowiednie do „poglądów” jest zachowanie pozwanego. W telefonicznej rozmowie $z$ audytorem powiada, że „nie ma ochoty", w liście do tegoż sędziego nazywa to, co powypisywal 
w pismach do Sądu, „zajęciem stanowiska”. Słowa pozwanego słabo przystają do rzeczywistości. Brak w tej sprawie przyznania się pozwanego do symulacji, brak w ogóle jakiejkolwiek jego wypowiedzi nadającej się do poważnego potraktowania. Jasno natomiast rysują się okoliczności zawierania tego małżeństwa przez pozwanego, osobę niereligijną, zgrywającą ważniaka, w sposób widoczny niepoważną. Jego wypaczone poglądy nie pozostają w sferze intelektu, lecz wyznaczają jego zachowanie (,nie ma ochoty zeznawać”). Z taką sylwetką charakterologiczną (i etyczną) trudno pogodzić wzbudzenie aktu woli, którym mężczyzna i kobieta w nieodwołalnym przymierzu wzajemnie się sobie oddają i przyjmują w celu stworzenia malżeństwa" (k.1057 §2). Pojęcie małżeństwa jako wspólnoty całego życia skierowanej ze swej natury do dobra małżonków oraz do zrodzenia i wychowania potomstwa (p.kan.1055 §1) było pozwanemu zupelnie obce. Wprawdzie brak na ten temat bezpośrednich wypowiedzi pozwanego, a przytacza się jedynie jego wypowiedzi odnośnie do potomstwa, jednak $z$ akt sprawy wynika, że wypaczona wola pozwanego dotyczyla nie tylko potomstwa, lecz małżeństwa jako takiego.

Symulacja (całkowita) małżeństwa to jego wykluczenie pozytywnym aktem woli (k.1101 §2). Z okoliczności zawarcia małżeństwa, lącznie z charakterystyką pozwanego, jasno wynika brak woli zawarcia malżeństwa, co jednak nie musi być równoznaczne z pozytywnym aktem woli wykluczającym małżeństwo. Podczas gdy w k.1057 jest mowa o akcie woli jako o - niczym do zastąpienia - przyczynie sprawczej małżeństwa, to kan. $1101 \S 2$ uznaje za nieważne jedynie małżeństwa zawierane z pozytywnym aktem woli przeciwnym. Ponieważ bez woli wymaganej k.1057 nie może zaistnieć ważne małżeństwo, nieważność takich związków nie ulega wątpliwości. Sporne jest, czy w takich przypadkach można powolać się na kan. $1101 \$ 2$ czy też - jak twierdzi większość autorów - na kan.1055 i 1057 (H.J.F. Reinhardt, Kriterien zur Unterscheidung zwischen dem Fehlen des Willens zum Ehevertrag und zur incapacitas assumendi, w: Valeat aequitas, Ksiegga ofiarowana R.Sobańskiemu, Katowice 2000, 363-374). Podstawą nieważności jest w takich przypadkach absentia consensus (H.Kahler, Absentia consensus, Frankfurt a M. 1999).

Nie przypadkiem w rozpatrywanej sprawie przyjęto obok symulacji niezdolność do podjęcia istotnych obowiązków małżeńskich jako tytuł nieważności. Granica między brakiem woli a niezdolnością jest płynna. Do Sądu należy kwalifikacja prawna sprawy, dokonana w wyniku 
przyporządkowania stanu faktycznego i wchodzących w grę przepisów. Zdaniem Sądu należy w rozpatrywanej sprawie przyjąć brak woli zawarcia małżeństwa. Co więcej, pozwany swoim zachowaniem przy protokole przedślubnym dowiódł lekceważącego, wręcz cynicznego podejścia do małżeństwa. Taki stan woli jest nie do pogodzenia $z$ wolą zawarcia malżeństwa. Poślubne dzieje tego malżeństwa świadczą, że takie nastawienie pozwanego trwało, wniosek stąd, ze wypaczało wolę pozwanego w chwili zawierania małżeństwa.

Tak więc Sąd stwierdza, że nie udowodniono nieważności małżeństwa $z$ tytulu niezdolności pozwanego do podjęcia obowiązków małżeńskich, udowodniono natomiast z tytulu wykluczenia małżeństwa. Tym samym Sąd orzeka nieważność małżeństwa.

La sentenza del Tribunale Metropolitano di Katowice (s. Sobański) del 27.12.2000 dal titolo della simulazione (,abrentia consersus")

\section{Sommario}

Si predenta il testo della sentenza del Tribunale Metropolitano di Katowice c. Sobański (,pro nullitate”) ob absentiam consensus. 